\title{
On the Ecological Vision of the Native Americans Exemplified in the Cartoon Pocahontas
}

\author{
XU Jun-fang \\ Jiangxi Normal University, Nanchang, China
}

\begin{abstract}
Pocahontas is an exquisitely made animation movie presented by Walt Disney in 1995. Since it was shown, the cartoon has received mixed reviews. Quite a few scholars have conducted postcolonial readings, and believe this movie offers a romantic and idealized version of the colonial history in an effort to cover up the truly brutal and cruel colonial reality. These readings put emphasis on the assimilation of Indian culture by mainstream white culture. This paper, however, argues that when they came to settle down on the American continent and exported their own values and cultures to the native Americans, European colonists absorbed the very essence of indigenous Indian culture: that is, the primitive environmental wisdom such as believing in the existence of spirituality as well as the coexistence and prosperity of man and nature. The paper aims to investigate the ecological philosophy of the Native Americans reflected in this movie from the perspective of Ecocriticism. The ecological vision of the Native Americans has become a legacy to all American people especially at a time when the American society reflects on the possible causes of the current environment challenges and hopes to build a harmonious ecosystem in which all species and living creatures may coexist and prosper.
\end{abstract}

Keywords: Native American, ecological, Pocahontas

\section{Introduction}

Co-directed by Mike Gabriel and Eric Goldberg, the cartoon Pocahontas was quite successful commercially, and won two Academy Awards for its achievement in music. This movie is centered on the story about the first settlers who came to Virginia led by Governor Ratcliffe. Driven by his greed, Governor Ratcliffe ordered his men to dig for gold and fire at the native inhabitants, which inevitably led to conflict with the native Indian population. A typical representative of the settlers Capitan John Smith, however, fell in love with Pocahontas, daughter of Chief Powhatan, leader of an Indian tribe. Eventually, the two lovers worked together and avoided the outbreak of conflict between the two parties. In the end, Governor Ratcliffe was sent back to Britain to face justice for the crime he committed; John Smith was seriously wounded as he tried to save the chief and had to return to London to be treated. Pocahontas, on the other hand, bore in mind her duty and mission to the people of her tribe and decided to stay. Obviously, this movie is a fine example of animated movies produced by Walt Disney, and it shows the look of American continent at the early period of the colonization. The scenes are quite beautiful; the theme song quite touching, and characters vivid and true-to-life. With all its attraction, there is still the quite clear

XU Jun-fang, lecturer, M.A., College of Foreign Languages, Jiangxi Normal University. 
flaw: In order to give an acceptable ending and a romantic coloring, the plot is sometimes far-stretched and impossible. In fact, the movie was adapted from a true experience: When he came to the settlement, John Smith was captured by an Indian tribe. When the chief determined to put him to death, he was rescued by Pocahontas the daughter of the chief and was released. This exciting experience haunted him for a long time in memory before he elaborated it in his work.

Since its show on screen, the movie has received considerable attention and had mixed reviews. Gene Siskel praises it "a surprisingly serious, thoughtful and beautifully drawn Disney animated feature". ${ }^{1}$ Readings have been done from the perspective of postcolonial criticism. For example, Chief Roy Crazy Horse criticized it as "historically inaccurate and offensive for glossing over more negative treatment of Pocahontas and her tribe by the British". ${ }^{2}$ This paper, however, attempts to analyze and investigate the Indian concept of environmentalism exemplified in a cartoon film Pocahontas. Ecocriticism is an interdisciplinary study of the environment and literary materials. It might be a relatively new literary approach since it did not achieve full development until 1970s. Ecocriticism focuses its attention on the relationship between literature and nature. Its purpose is to examine and analyze texts that are concerned with the environment, and to reveal the ideas of ecological holism and environmentalism in them. The thoughts of anthropocentrism that came along with economic industrialization makes us abandon the primitive awe and worship we once held towards nature. Nature has become just the object succumbed to human conquest, and its only value is to meet the needs of human being. In the current society when we are faced with worldwide ecological crisis, many people have realized the problems we have caused to our natural environment. This awareness has naturally found its way to an increasing number of films, songs, literary works, etc. American Indian environmental philosophies have exerted a strong impact on Ecocriticism.

\section{The Indians' Plain Outlook That Worships Mother Earth and Believes in Spirituality}

With all their differences, many Indian tribes share a common belief: A Great Spirit created the earth and pervaded everything. The Indians believe in the spiritual being of all living things and consider the earth itself to be a vital and complete organism, a stable, balanced, and complete ecosystem. The Indians adhere to an environmental ethics that emphasizes the importance of paying respect to nature and coexisting with nature harmoniously. Humans have no privilege in nature and should not be put to the top of the rank of life. What humans should do is to set out to nature, and let nature be our guide, restore us to the simple and pure situation of the old time, and respond intuitively to the beauty of nature. We should not be so ambitious as to impose our ideas to nature, or conquer nature. We must obey the laws of nature, and keep harmony with it. Only by doing so, humans can return to a divine state of "man and nature in one". In Western thoughts and discourse, however, nature means a physical world that humans should separate and distinguish from. Nature is the counterpart of human being, the subject of human labor. The ecological viewpoints of the Native Americans show the power of ancient wisdom, and are enlightening to our consideration of human fate.

To John Smith, Pocahontas is not only a charming exotic beauty, but more importantly a guide for him to appreciate beauty of nature.

\footnotetext{
${ }^{1}$ Pocahontas (1995 film) [EB/OL]. See https://en.Wikipedia.Org/wiki/Pocahontas_(1995_film).

${ }^{2}$ Ibid.
} 
You think you own whatever land you land on; the earth is just a dead thing you can claim. But I know every rock and tree and creature has a life has spirit has a name... We are all connected to each other in a circle in a hoop that never ends. $^{3}$

These lyrics of the theme song "Colors of the Wind" perfectly shows us the Native Americans' plain outlook of nature that has taken shape since the ancient time. The Indians believe that rivers, land, and wind are not just elements of nature, but have their own divine power. In this movie Pocahontas, wind is an important ecological image. It brings the guidance of mother earth, and is always present when John Smith and Pocahontas meet. It not only strengthens the romantic atmosphere, but also shows that this love is approved and arranged by mother earth. In the movie, love sweeps aside misunderstanding and makes it possible for people with such total different values to understand, appreciate, and love each other. It is a utopian situation in which people of different races and background can mutually respect and understand each other.

Whether we are white or copper-skinned, we need to sing with all the voices of the mountain, need to paint with all the colors of the wind. You can own the earth and still all you'll own is earth until you can paint with all the colors of the wind. $^{4}$

Wind is also a symbol of hope, freedom, and vigor. Pocahontas resembles the wind in that she is free both physically and spiritually, always pursuing her dream. The wind curls up her long hair, which brings her a touch of natural beauty. Another crucial ecological image is the Grandmother Willow, who gives her advice, confidence, and courage. When Pocahontas felt at a loss about her future, Grandma Willow asked her to be quiet and listen to the guidance of the spirits in the soil, water, and sky. With the guidance of Grandmother Willow, Pocahontas finally made up her mind and knew her choice at a crucial moment. These ecological images create a vivid picture of human living in a divine world with pervasive spirits everywhere.

\section{The Aboriginal Simple Lifestyle of the Native Americans}

Indians believe that they must observe and imitate the universal order and thus live a life that is in balance and harmony with creation. Its traditional way of life is one in conformity to the universe and natural order. They rise with the sun in the morning, rest and ponder in the dark after sunset. Indians do not pursue either comfortable luxurious conditions of life or excessive material wealth, or more resources and property than necessary. They are content with their simple and plain lifestyle. This lifestyle is marked with simplicity and minimalism without the benefits and conveniences brought about by modern science and technology. Yet, they feel peaceful, satisfied, and rich spiritually. Life, to Indians, is a cycle which is made up stages like birth, growth, and death. When people die, their soul returns to the Great Spirit, and the energy of the earth remains stabilized. This simple and plain lifestyle was admired and imitated by lots of Americans among whom Henry David Thoreau is the best representative.

Indians have a strong awareness of land protection and love the sacred land which brings them harvest and food. In order to protect their own land and home, they fought courageously their invaders against all odds. In strong contrast, the settlers led by the governor came here primarily to seek gold and other resources in the movie Pocahontas. They just took for granted that all the resources they found should be used to meet human needs.

${ }^{3}$ Colors of the wind lyrics [EB/OL]. See http://www.stlyrics.com/lyrics/classicdisney/colorsofthewind.htm.

${ }^{4}$ Ibid. 
Land was just a tool humans used to make profit. The governor could not wait to declare the land owned and named it Jamestown, and felled down the trees in the area. He ordered his men to slaughter and drive the "savages" away in order to take the spoil of land and other resources. The settlers just greedily went after gold and material wealth. Even the words said by John Smith gave away his Eurocentralism. When Pocahontas asked Smith about their intention of coming here, he said "we come here to help you build houses, roads, bring you freedom, prosperity and fortune". Obviously they viewed themselves as the spreader of advanced civilization marked with freedom and prosperity, but harbored a sense of superiority secretly inside. The colonists tried to find excuses for their plunder which, of course, were not acceptable by Pocahontas. When John Smith, on another occasion, asked about gold, Pocahontas said she did see some, and later showed him the corn. For the Indian people, food is far more important and precious than gold, and they are grateful because they are richly endowed by Mother Earth so they would not be hungry. They believe, in turn, they have an obligation to reciprocate its nurturing of the people: Be caretakers of the land and mother earth. To the Indians, land not only provides physical sustenance, but also defines identity, both tribal and individual. "Environmental factors play a crucial role in the physical, emotional, and even spiritual configurations that determine our ideas of who we are" (Dreese, 2002 , p. 1). Because the importance of land in the minds of native Indians, they would seldom leave their home. Their concept of self is closely linked with the place where they grew up and the landscape has embedded in their character and identity as a human being.

Native Americans firmly believe that spirit is inherent in every form of life, and thus humans have kinship with all creatures of the earth. Humans are equal and dependent on animals and plants. Indians would hunt animals just for food, of course, but they would not take more than they need. The act of hunting is a process of understanding and communication with the animal. Indians' understanding about themselves is closely bound to their understanding of animals. They reckon animals to be their equal and intimate friends. Like in the movie, two cute animals followed Pocahontas everywhere and kept her company: Meeko, a raccoon and Flit, a hummingbird. They brought her joy and happiness. They were by no means pets, but her friends, loyal companions, even family members equally treated.

\section{Indian Women's Metaphorical Correspondence With Nature}

In a Greco-Christian patriarch society, women are nothing but subjects of men's power, and remain obedient and voiceless to men's domination in the society. According to the system of values set up in the West, women are a collective concept that is associated with passiveness and disadvantage. Eco-feminism identifies a mysterious, natural link between women and nature. The female body has become an image of nature and land. In many cultures across the world, nature is compared to mother with some female characteristics. Nature succumbs to human in a similar way women are subordinated by men.

In Indian tribes, men and women have different division of labor, but women's status is not low. Females are respected because of their contribution to the tribe: giving birth. Women gather food and bring up the children while men fight the enemy and protect their home. At the every beginning of Pocahontas, we see a busy and lively picture of the Indian tribe. Everyone is happy celebrating the bumper harvest. Bare-footed women gather fruit in the fields, their baskets full of fruits and corn. Indian women are closely connected with mother earth. They have been cultivating the land and bearing children on this continent generation after generation. They are 
full of vigor and life and stand in correspondent to this fertile and rich land. Pocahontas is a typical Indian girl who is not only pretty and sexy with long black hair, but also smart and wise beyond her age. With dark skin, black eyes, and long hair, she is an ideal symbol of beauty of eastern woman. Her charm is most derived from her close connection with nature. She is young, active, agile, and wild. No wonder John Smith would inevitably be drawn to her after getting tired of the ladies in Europe. She adores and embraces the beauty of nature, and is also part of it herself. As the chief's daughter, she was engaged actively in the affairs of the tribe, brave enough to express her opinion. She was supposed to marry Kocoum, a warrior of her own tribe who was strong, muscular, and courageous yet too serious. Kocoum had already accepted Pocahontas as his wife and planed to lead the people with her after the chief dies. She was attracted by John Smith after meeting him. She followed her heart about her feelings toward Smith and bravely admitted to her father and won his respect. She dated Smith and saved him at risk of her own life and convinced her people. She took up the responsibility of protecting her people and her home. She tried to understand her opponent when she found they were far more advanced. She never forgot her duty to the people even in love and decided to stay with her people, to take care of the land as well as the plants and animals, which shows her self-sacrifice and the sense of responsibility. This ending should come as no surprise, because the daughter of nature is not supposed to leave her land. Her identity is directly linked to the land she lives in. Only by living in this unspoiled land of virgin, can she truly live freely. If she went to Europe and stayed together with Smith, her charm would definitely leave her, and she would become just one of Smith's women and lose her identity and self. At the end of the movie, love prevailed over greed, the two sides found a compromise. But this compromise is only possible when a brilliant member of white settlers understands the Indian culture because he falls in love with an Indian girl and volunteers to become the agent of communication for the two cultures, which is obviously an emphasis on the white male's domination. Pocahontas falls into the stereotyped images of the Native American females, created based on the imagination of westerners on Indians women, a combination of exotic beauty and strong mind.

\section{Conclusion}

In the highly developed industrialized world, economic growth is often pursued at the expense of natural environment. The modern society has realized the inevitable damage to environment that comes along with excessive economic growth and started to consider the solutions for current environmental crisis. The Indian ecological visions have been implanted into the American mainstream culture, and have exerted their profound influence. This paper argues that when they came to settle down on the American continent and exported their own values and cultures to the Native Americans, European colonists absorbed the very essence of indigenous Indian culture: that is, the primitive environmental wisdom such as believing in the existence of spirituality as well as the coexistence and prosperity of man and nature. The animated movie Pocahontas is a reflection of this ecological philosophy and the message it tries to convey to its audience is that Eurocentric ideology should be dismantled and there are lessons we can immensely learn from the Native Americans. The Indian ecological vision shows their primitive wisdom of maintaining in balance with nature. And the Indians' traditional way of living harmoniously with nature has become an ideal mode of existence in the contemporary American society. The advocacy of Indian ecological philosophy provides one way of solving the current crisis we face nowadays and arousing the concern of the general public on the importance of environmental protection. 


\section{References}

Alarcon, N. (1992). Chicana feminism: In the tracks of "the" native woman. In J. Trimmer and T. Warnock (Eds.), Understanding others: Cultural and cross-cultural studies and the teaching of literature. Urbanna: NCTE.

Booth, A. L., \& Jacobs, H. L. (1990). Ties that bind: Native Amercian consciousness as a foundation for environmental consciousness. Environmental Ethics, 12(1), 27-43.

Colors of the wind lyrics [EB/OL]. (n.d.). Retrieved from http://www.stlyrics.com/lyrics/classicdisney/colorsofthewind.htm

Dreese, D. N. (2002). Ecocriticism: Creating self and place in environmental and American Indian literatures. New York: Peter Lang.

Pocahontas (1995 film) [EB/OL]. (n.d.). In Wikipedia. Retrieved from https://en.Wikipedia.Org/wiki/Pocahontas_(1995_film) 